\title{
Influence of Leadership and Organizational Citizenship Behaviour (OCB) on Employee Performance
}

\author{
R. Joko Sugiharjo \\ Faculty of Economics and Business, University of Mercu Buana
}

\begin{abstract}
This research is classified as causal research that aims to determine the influence of Leadership and Organizational Citizenship Behavior (OCB) on the Employee Performance of SMK Negeri 1 Karawang staffs. The sample used was 50 respondents who are employees and supported by primary data collection techniques. The method used in this research is a Partial Least Square (Smart PLS) Version 3. The results of this research indicate that Leadership variable have a positive and significant effect on the Employee Performance of SMK Negeri 1 Karawang staff. And Organizational Citizenship Behavior (OCB) variable have a positive and significant effect on the Employee Performance of SMK Negeri 1 Karawang staff.
\end{abstract}

Keywords : Leadership, Organizational Citizenship Behavor (OCB), Employee Performance.

DOI: $10.7176 / \mathrm{JRDM} / 62-06$

Publication date: January $31^{\text {st }} 2020$

\section{INTRODUCTION}

Organization is a group of living human beings who come together to achieve a goal. Therefore, we can not see this organization as inanimate objects that can be treated arbitrarily. A special treatment needed to keep the organization alive and growing. Human Resources is the most important factor in the survival of the organization. Human is the founder, designer, workers, observers, and decision maker of an organization. Therefore, the ideal management concepts must be centered on the human being. Similar with the company within human working environment affect the organization's progress. Human performance is indispensable in any institution, in terms of skill, motivation, until the character of a person to cooperate with these institutions must be selected with appropriate qualifications.

Organizations must believe that to achieve excellence, they need to reach individual performance as high as posible. Basically, the individual performance affects the performance of the team and ultimately affect the overall performance of the organization. The demanded behavior of the organization not only in-role behavior but also extra-role behavior. Extra-role behavior is very important because it provides better benefits to support the sustainability of the organization (Oguz, 2010). Extra-role behavior within the organization known as the Organizational Citizenship Behavior (OCB). Organizational Citizenship Behavior (OCB) is an attitude that many organizations expect to have in its employees. That is because Organizational Citizenship Behavior (OCB) is considered to benefit an organization that cannot be grown on the basis of formal role obligations or by contract or recompensation forms.

In this work before the employee joins, they need to meet the criteria. Therefore, organizations hold administrative profiles selection of prospective employees aim to find a job that fits their education and experience. After that, there are the next selection test, which is psychological test, to find out about the intelligence capabilities also in addition it will show comprehension of working. Continue with interview to get to know more about the prospective employees from their character and readiness to join the work in the organization that will be visible. Last, medical ceck up to determine the health of the prospective employee. If the prospective employee has met all the requirement and will join the organization, the prospective employees will be informed for the tenure agreement. In the work period there are several stages, namely a 6 months training period, a trial period of 1 year, if it has passed the trial period it will be invaluable in working for the employee to decide whether the work period will expire or remain as the employee.

In addition to self-ability, employees consider as members of the organization must have harmonious ties with other members in order to achieve goals precisely and cover the lack of knowledge in each of its members. The solidarity that we often hear is very important and it affect the work that we face which interrelated in the work ties in each of its divisions in order to achieve organizational targets. Therefore, professional between members, and mutual respect is very necessary. An organization will succeed in achieving the goals of its programs if the people who work in the organization can perform tasks well in accordance with their respective fields and responsibilities.

So that people in the organization can carry out their duties properly, it is necessary to have a leader who can motivate to direct all available resources towards the achievement of goals. A Research from (Maulizar, 2012) " Evaluating the ability and potential of each subordinate to carry out a task or work at Bank Syariah Mandiri, also increases the responsibilities and authority of subordinates in the future", (Ningrum and Prihatsanti, 2014) "In PT. $\mathrm{X}$ Bank a leader motivates subordinates to work optimally in order to achieve objectives of the company and a 
leader who provides inspiration and innovation to the company ", (Kharis, 2015) "In JATIM Bank leader must inspires subordinates to put aside their personal interests and have extraordinary ability to influence". Based on these studies, the focuses on leadership in this research is the influence of leadership in employee performance.

Another phenomenon that occurs in SMK 1 Karawang is Organizational Citizenship Behavior (OCB), In every organization, including government organizations, there is an Organizational Citizenship Behavior (OCB), which is an informal, voluntary regulation. With Organizational Citizenship Behavior (OCB), it is expected that the staff to be more integrated with the work environment. Organizational Citizenship Behavior $(O C B)$ is urgently needed in organizations such as SMK Negeri 1 Karawang, in which interconnectedness and mutual need are no exception to the loyalty, compliance, and participation of fellow divisions involved.

Based on the above description, the researchers took the title, "The Influence of Leadership and Organizational Citizenship Behavior (OCB) on Employee Performance of SMK 1 Karawang Staff ". The problem identified are as follows:

a. Does leadership affect the performance of the staff at SMK Negeri 1 Karawang?

b. Do Organizational Citizenship Behavior (OCB) affect the performance of the staff at SMK Negeri 1 Karawang?

Based on the description above, the formulation of research problems that will be disclosed author in this research are:

a. How does the Influence of Leadership on Employee Performance of SMK 1 Karawang staff?

b. How does the Influence of Organizational Citizenship Behavior (OCB) on Employee Performance of SMK 1 Karawang staff?

The objective of the research is:

a. To identify the leadership influence on the performance of the staff at SMK Negeri 1 Karawang.

b. To determine the Organizational Citizenship Behavior (OCB) on the performance of the staff at SMK Negeri 1 Karawang.

Based on the objectives stated above, this research is expected to have the following benefits:

a. Theoretical Contributions

The results of this research are expected to provide benefits and expand a rationale for the development of science in the field of human resources management, particularly on the Effect of Leadership and Organizational Citizenship Behavior (OCB) on staff at SMK Negeri 1 Karawang and become a source of information for readers who are interested in doing research with the same problem.

b. Practical contribution

From the results of this research are expected as a reference and input material as thought contribution to SMK 1 Karawang, in order to deeply produce more leaders that motivates and a better Organizational Citizenship Behavior (OCB) in order to increase the organization's goals.

\section{LITERATURE, FRAMEWORK, AND HYPOTHESES}

\section{A. Literature review}

In literature review the theoretical basis of the research will be described, which is useful as a basic premise when discussing the issues, and to underlying the analysis to be used in the next chapter about Leadership and Organizational Citizenship Behavior (OCB) on employee performance to produce a cooperation between employees and leaders, as well as produce the behavior of the employees who reach more than expected and work unitedly to build a united world.

\section{a) Human Resource Management}

According to Mangkunagara (2009) Human resource management is a planning, coordinating, implementing and supervision towards the procurement, development, provision of services replies, integration, maintenance, and the division of labor in order to achieve organizational goals.

\section{b) Employee performance}

Performance is the result of quality and quantity of work achieved by a person in performing the tasks assigned to him in accordance with the standards or criteria established. Performance shows the success rate of employees in carrying out their duties and responsibilities. The higher performance of the employee, then the overall organizational productivity will increase. Prawirosentono (2008) states that performance is the result of work that can be achieved by a person or group of people within an organization in accordance with the authority and responsibilities of each in order to attempt to achieve organizational goals legally and not violate the law and in accordance with moral and ethical. Zainur (2010) defines, "Performance is the whole process of individual working which results can be used as basis for determining whether an individual's work is good or otherwise".

Indonesia Dictionary (2008) defines the employee as a person who works in an institution (offices, companies, etc.) to receive salary or wages. According to Akmal, et al (2012), employee performance or 
achievement is the result of the work specified by the organization. The excellent performance is the optimal performance, which is the performance of appropriate standards organization and support the achievement of organizational goals.

c) Leadership influence

Leadership as a management concept in the life of organization that has a strategic position and is a social phenomenon that is always needed in the life of the group. Leadership has a strategic position because leadership is the central point and the dtnamist of whole organizational activities process. So, the leadership has a central role in determining appropriate policies in the organization in accordance with the existing resources.

d) Organizational Citizenship Behavior (OCB)

According to Titisari (2014), Organizational Citizenship Behavior (OCB) is an individual contributions that exceed the demands of the role of the workplace. Organizational Citizenship Behavior (OCB) is a company employee behavior shown to improve the effectiveness of the company's performance without ignoring individual employee productivity goals. Organizational Citizenship Behavior (OCB) is considered as a workplace behavior that is in accordance with personal assessments that exceed a person's basic work requirements.

According to Robbis and Judge (2014), Organizational Citizenship Behavior (OCB) is the freedom behavior to determine that is not part of the formal requirements of the job but contributes to the psychological and social environment of the workplace. In general, there are three main components of Organizational Citizenship Behavior (OCB), that is, the behavior is more than a formal requirement or job description that has been determined, the action is not concerned with training (natural) or in other words people do the action voluntarily and the action is not rewarded with formal rewards by the organization.

\section{B. Framework}

Based on the literature review and previous studies, the researchers formulated the following framework:

Figure I

\section{Framework of Research}

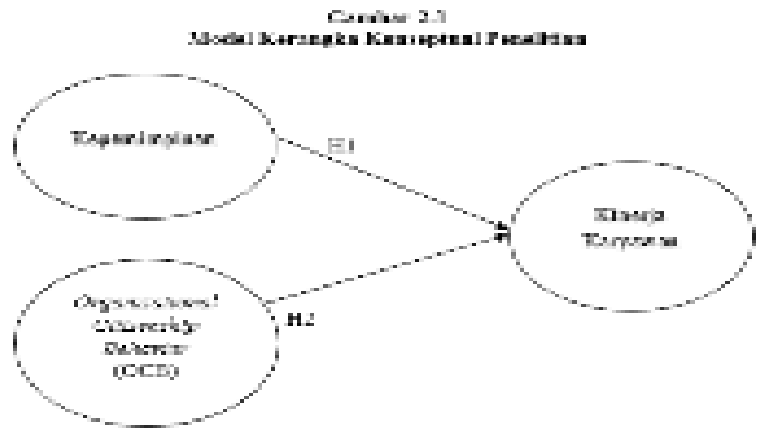

\section{Hypothesis}

Based on the relationship between framework variables then the researcher formulate hypotheses as follows:

H1 : Leadership has positive and significant effect on employee performance.

H2 : Organizational Citizenship Behavior (OCB) has positive and significant impact on employee performance.

\section{RESEARCH METHODS}

A. Time and Place Research

a) Time Research

This research was conducted in August 2018 until July 2019 to meet the needs of data and information. This research was carried out in stages using a pre-survey, starting from the introduction, research testing, filing a permit, consulting, and making a questionnaire and processing thesis preparation data.

b) Place Research

In the preparation of this research, the authors conducted research in SMK Negeri 1 Karawang located at Jalan Tanjung Pura Base Struggle Karawang.

\section{B. Research design}

For the research design, the authors use causal research methods. According to Sugiyono (2013) causal design that is a causal relationship between the independent variables and the dependent variable. This research was to 
determine the effect of one or more independent variables on the dependent variable with hypothesis testing using statistical test.

\section{Definitions and Operational Variables}

According to Sugiyono (2009) research variables are basically everything in the form of whatever which determined by researchers to be studied so that information is obtained about it, then conclusions are drawn.

D. Population and Sample Research

a) Population

According to Rochaety, el al (2009) population is a group of people, events or things possessed with certain characteristics. In this research the subject of research is the staff of SMK Negeri 1 Karawang address at the Pangkal Perjuangan Street, Tanjung Pura, Karawang. The population of this research are staff of SMK Negeri 1 Karawang as many as 50 people.

b) Samples

According to Sugiyono (2013) sample is part of the number and characteristics possessed by the population, we can conclude that the sample is respondents selected by researchers for research data. The sample used in this research is saturated samples (census) sampling technique when all members of the population used as a sample. Saturated Sampling is a sampling technique when all members of the population used as a sample. This is often done in less than 50 people, or research that aim to make generalizations with errors.

E. Data analysis method

a) Descriptive analysis

According to Sugiyono (2013) descriptive analysis is a statistic used to analyze data by illustrating or describing data that has been collected as it is without intending to make conclusions that apply to the public or generalizations. Activities in data analysis are grouping based on variables and types of respondents, tabulating data based on variables from all respondents, presenting data for each variable studied, doing calculations to answer the problem formulation, and doing calculations to test hypotheses that have been proposed.

b) Instruments Test

i. Validity test

Each instrument arrangement in the research always takes into account several considerations such as what would be measured, whether the data collected is relevant to the desired trait or characteristic, and the extent to which the difference in scores obtained reflects the characteristics to be measured.

ii. Reliability test

Reliability implies that an instrument can be trusted to be used as data collection because the instrument is already good. A good instrument will not be tendentious in directing respondents to choose certain answers. Reliable instruments that are reliable can produce reliable data.

c) Partial Least Square Analysis

i. Partial Least Square

SEM (Structural Equating Modeling) - PLS (Partial Least Square). Structural Equating Modeling (SEM) is an analytical technique that allows testing a series of relationships simultaneously (Noor, 2011). This relationship is built between one or several independent variables with one or several dependent variables. The method of data analysis in this study uses component or variance based Structural Equation Modeling (SEM) where the data processing uses the Smart-Partial Least Square (Smart-PLS) version 3.0 program. PLS (Partial Least Square) is a model of variance-based SEM. PLS is intended for causal predictive analysis in situations of high complexity and low theoretical support (Ghozali, 2014)

ii. Average Variance Extracted (AVE)

The model has sufficient discriminant validity if the root of AVE for each construct is greater than the correlation between constructs and other constructs. Assessing the validity of a construct by looking at the AVE value, requires a good model if the AVE of each construct is greater than 0.50 (Ghozali, 2014).

\section{RESULTS AND DISCUSSION}

A. Descriptive statistics

a) Respondents Characteristics

Based on the results of research conducted on 50 respondents, namely the staff of SMK Negeri 1 Karawang, it can be seen an overview of the characteristics of respondents by gender, age, education level, length of service and status. For more details, below are presented individually on a general overview of the research respondents.

i. Characteristics of Respondents by Gender

Data of respondents by sex can be seen in the table below: 
Table I

Characteristics of Respondents by Gender

\begin{tabular}{|c|l|c|c|c|c|}
\hline \multicolumn{2}{|c|}{} & frequency & Percent & valid Percent & Cumulative Percent \\
\hline \multirow{3}{*}{ valid } & Woman & 30 & 60.0 & 60.0 & 60.0 \\
\cline { 2 - 6 } & Men & 20 & 40.0 & 40.0 & 100.0 \\
\cline { 2 - 6 } & Total & 50 & 100.0 & 100.0 & \\
\hline
\end{tabular}

Sources: Primary data processed by researcher, 2019

From the above data can be seen by the grouping by gender, then of 50 respondents there were 30 respondents or equal to $60 \%$ of female, and there are 20 respondents or equal to $40 \%$ are male.

ii. Characteristics of Respondents by Age

Characteristics based on the age of respondents SMK 1 Karawang can be seen in the table below:

Table II

Characteristics of Respondents by Age

\begin{tabular}{|c|c|c|c|c|c|}
\hline \multicolumn{2}{|c|}{} & frequency & Percent & valid Percent & Cumulative Percent \\
\hline \multirow{5}{*}{ valid } & $18-22$ y.o. & 3 & 6.0 & 6.0 & 6.0 \\
\cline { 2 - 6 } & $23-28$ y.o. & 13 & 26.0 & 26.0 & 32.0 \\
\cline { 2 - 6 } & $29-34$ y.o. & 17 & 34.0 & 34.0 & 66.0 \\
\cline { 2 - 6 } & $35-40$ y.o. & 12 & 24.0 & 24.0 & 90.0 \\
\cline { 2 - 6 } & $>40$ y.o. & 5 & 10.0 & 10.0 & 100.0 \\
\cline { 2 - 6 } & Total & 50 & 100.0 & 100.0 & \\
\hline
\end{tabular}

Sources: Primary data processed by researcher, 2019

From the above table can be seen by grouping the age of the respondent, from 50 respondents aged 29 - 34 years old as many as 17 people (34\%), respondents aged 23 - 28 years old as many as 13 people (26\%), while respondents aged 35 - 40 years old as many as 12 people $(24 \%)$, then to respondents aged $>40$ years old as many as 5 people $(10 \%)$, and for respondents aged $18-22$ years old as many as 3 people $(6 \%)$.

iii. Characteristics of Respondents by Education Level

Data of respondents by level of education can be seen in the table below:

From the figure can be seen by the grouping of respondents' education level, the 50 respondents, respondents were educated on the S1 (bachelor) educational level as many as 37 people (74\%), while respondents on D3 (diploma) education level as many as 26 people (26\%).

iv. Characteristics of Respondents Based on the Length of Works

Data respondents by length of work can be seen in the figure below:

\section{Table IV}

Characteristics of Respondents Based on the Length of Works

\begin{tabular}{|c|c|c|c|c|c|}
\hline \multicolumn{2}{|c|}{} & frequency & Percent & valid Percent & Cumulative Percent \\
\hline \multirow{6}{*}{ valid } & $0-1$ years & 2 & 4.0 & 4.0 & 4.0 \\
\cline { 2 - 6 } & $1-2$ years & 7 & 14.0 & 14.0 & 18.0 \\
\cline { 2 - 6 } & 2 - 3 years & 6 & 12.0 & 12.0 & 30.0 \\
\cline { 2 - 6 } & $3-4$ years & 10 & 20.0 & 20.0 & 50.0 \\
\cline { 2 - 6 } & > 4 years & 25 & 50.0 & 50.0 & 100.0 \\
\cline { 2 - 6 } & Total & 50 & 100.0 & 100.0 & \\
\hline
\end{tabular}

Sources: Primary data processed by researchers, 2019

From this table, it can be seen based on the grouping based on the length of work of respondents, the number of respondents who have worked for 0 - 1 year as many as 2 people (4\%), respondents who have worked for $1-2$ years as many as 7 people (14\%), respondents who have the length of work 2 - 3 years is 6 people $(12 \%)$, respondents who have worked 3 - 4 years are 10 people (20\%), and those who have worked $>4$ years are 25 people (50\%).

\section{v. Characteristics of Respondents by Status}

Data of respondents by status can be seen in the table below: 
Table V

Characteristics of Respondents by Status

\begin{tabular}{|c|l|c|c|c|c|}
\hline \multicolumn{2}{|c|}{} & frequency & Percent & valid Percent & Cumulative Percent \\
\hline \multirow{3}{*}{ valid } & Married & 36 & 72.0 & 72.0 & 72.0 \\
\cline { 2 - 6 } & Single & 14 & 28.0 & 28.0 & 100.0 \\
\cline { 2 - 6 } & Total & 50 & 100.0 & 100.0 & \\
\hline
\end{tabular}

Sources: Primary data processed by researcher, 2019

Based on the above table shows that out of 50 respondents there were 36 respondents or $72 \%$ that are married. While the rest are 14 respondents or $28 \%$ are unmarried. It can be concluded that the majority of employees who work on the staff of SMK Negeri 1 Karawang already married.

B. DATA QUALITY TEST RESULTS

a) Evaluation of Measurement (Outer) Model

i. Convergent Validity

Convergent Validity Testing of each construct's indicator. According to Chin in Ghozali (2014), an indicator is said to have a good valid if the value is greater than 0.70 , while the loading factor of 0.50 to 0.60 can be considered sufficient.

\section{Figure II}

\section{PLS Algorithm Results}

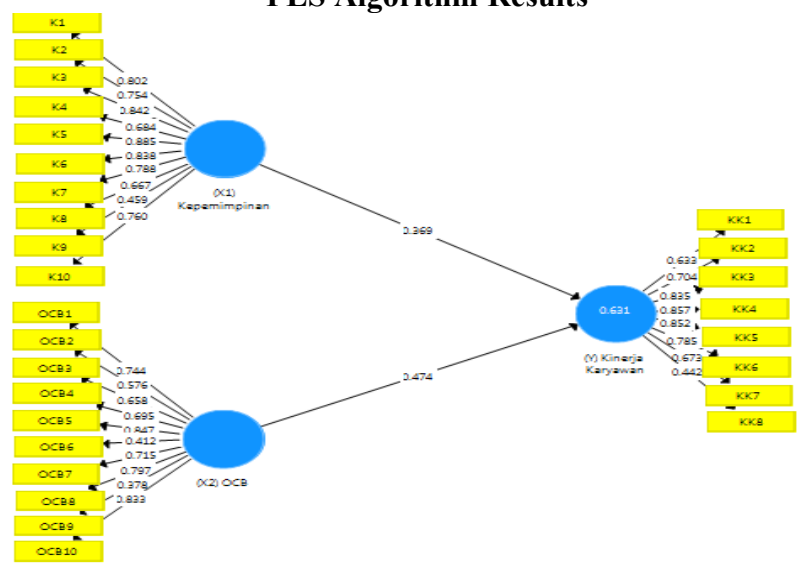

Source: PLS Output

Based on the tables and the picture above, it appears that the indicators of $\mathrm{K} 9$, OCB6, OCB9, and KK8 has a loading factor value of less than 0.50 . Therefore, the indicator will be removed from the model.

ii. Composite Reliability and Cronbachs Alpha

Composite Reliability and Cronbachs Alpha Testing aims to test the reliability of the instrument in a research model, if the entire value of the latent variable has a Composite Reliability and Cronbachs Alpha value $>0.70$ it was shows that the constructs have good reliability or questionnaire that is used as a tool in research has been consistent. Here is the value of Composite Reliability and Cronbachs Alpha at the output.

Table VI

Composite Reliability Testing Results

\begin{tabular}{|c|c|c|}
\hline & composite Reliability & Information \\
\hline Leadership & 0.936 & reliable \\
\hline OCB & 0.910 & reliable \\
\hline Employee performance & 0.909 & reliable \\
\hline
\end{tabular}

Source: PLS Output

Table VII

Cronbach's Alpha Testing Results

\begin{tabular}{|l|c|c|}
\hline & Cronbach's Alpha & Information \\
\hline Leadership & 0.923 & reliable \\
\hline OCB & 0.891 & reliable \\
\hline Employee performance & 0.884 & reliable \\
\hline
\end{tabular}

Source: PLS Output

Based on the above table it can be seen that the test results of Composite Reliability and Cronbachs Alpha showed a satisfactory value that is all latent variables have been reliable because the entire value of latent 
variable have Composite Reliability and Cronbachs value $>0.70$. So, it can be concluded that the questionnaires used as a research tool has been reliably or consistently.

b) Structural Model Testing / Hypotheses Test (Inner Model)

Testing inner model is a model-based development concept of theory in order to analyze the relationship between exogenous and edogen which have been outlined in the conceptual framework. Stages testing of structural models (hypothesis testing) is performed with the following steps:

\section{i. R-Square value}

Tests on structural models done by looking at the value of R-square is a test for goodness-fit model. The results of the R-square for endogenous latent variables can be seen in the following table:

\section{Table VIII}

Endogenous Variable $\mathbf{R}^{2}$ value

\begin{tabular}{|c|c|}
\hline Variables & R-Square (R) \\
\hline Employee performance & 0.633 \\
\hline
\end{tabular}

Source: PLS Output

From the above data it can be concluded that the R-square value is 0.633 which means that the variability of employee performance can be explained by two variables Leadership and Organizational Citizenship Behavior (OCB) amounted to $63.3 \%$, while $36.7 \%$ is explained by other variables not examined in this model.

\section{ii. Hypothesis Testing Results (Path Coefficient Estimation)}

The estimated value for the path relationship in the structural model must be significant. This significant value can be obtained by the bootstrapping procedure. Looking at the significant of the hypothesis by looking at the value of the parameter coefficient and t-statistical significance value on the bootstrapping report algorithm. To see significant or insignificant it is seen from the t-table at alpha $0.05(5 \%) 1.96$. Then $\mathrm{t}$-table is compared with t-count ( $\mathrm{t}$-statistics).

Table IX

Hypothesis Testing Results

\begin{tabular}{|l|l|l|l|l|l|}
\hline & Original sample (O) & Sample Mean (M) & Standard Dev & T Statistics & P-Values \\
\hline $\mathrm{K} \rightarrow \mathrm{KK}$ & 0.413 & 0.401 & 0.115 & 3.598 & 0.000 \\
\hline $\mathrm{OCB} \rightarrow \mathrm{KK}$ & 0.439 & 0.467 & 0.105 & 4.196 & 0.000 \\
\hline
\end{tabular}

Source: PLS Output

Figure III

Bootstrapping Test Result

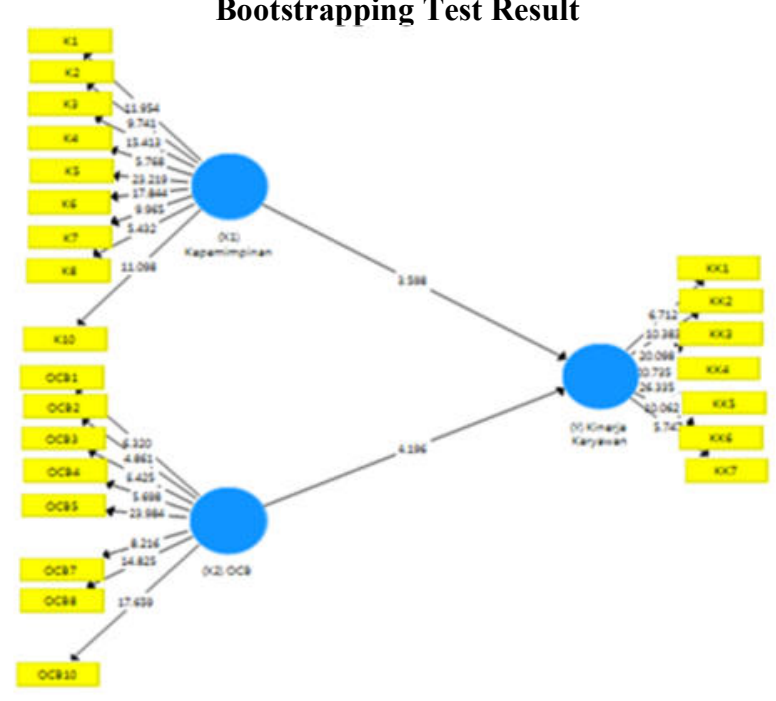

Source: PLS Output

\section{DISCUSSION OF RESEARCH}

a) Influence of Leadership on Employee Performance

Based on the hypothesis test in this study, the T-statistic value was 3.598 and the original sample value is 0.413 . The T-statistic value is greater than the T-table value of 1.96 and the original sample value shows a positive value, this result shows that Leadership has a positive and significant effect on Employee Performance. This is because the leader never gives appreciation / appreciation to the staff of SMK Negeri 1 Karawang so that the relationship with employee behavior is not loyal to the school, basically every member of the organization needs appreciation / appreciation as a form of concern from the leader. The results of this hypothesis were reinforced by Wihardi, 
Pradhanawati, and Susanto (2014), Utami (2015) which stated that Leadership had a positive and significant effect on Employee Performance.

b) Influence of Organizational Citizenship Behavior (OCB) the Employee Performance.

Based on the hypothesis test in this study, the T-statistic value was 4.196 and the original sample value was 0.439 . The T-statistic value is greater than the T-table value of 1.96 and the original sample value shows a positive value, this result shows that Organizational Citizenship Behavior (OCB) has a positive and significant effect on Employee Performance. This is because, the low Organizational Citizenship Behavior (OCB) in the Staff of SMK Negeri 1 Karawang, so that the staff of SMK Negeri 1 Karawang in their work are not loyal in terms of time because most of the staff do not have the availability of voluntary feelings to go home from work more than time has been determined to complete the work and the attitude between employees is seen that each does not care about the other employees so there is no sense of unity to improve school progress. The results of this hypothesis are strengthened by research by Fitriastuti (2013), Kimbal et al (2015), Ticoalu (2013) which states that Organizational Citizenship Behavior (OCB) has a positive and significant effect on employee performance.

\section{CONCLUSIONS AND RECOMMENDATIONS}

A. Conclusion

After the researchers conducted research and discussion in previous sections on the Effect of Leadership, Organizational Citizenship Behavior (OCB), on Employee Performance in Staff of SMK Negeri 1 Karawang, the following conclusions can be drawn:

a) Leadership has a positive and significant effect on employee performance. It can be concluded that the increase in employee performance is due to the application of leadership.

b) Organizational Citizenship Behavior (OCB) has a positive and significant effect on employee performance. It can be concluded that the increase in Employee Performance is due to the application of Organizational Citizenship Behavior (OCB).

\section{B. Suggestion}

Based on the results of the research the following suggestions can be given:

a) Suggestions for companies

In the Leadership variable, the smallest answer value is the K-09 indicator, "My leader always gives awards to employees who excel in all fields". This means that some respondents felt lack of acknowledgement / appreciation from leaders towards SMK Negeri 1 Karawang staff, because basically every member of the organization needs an award as a form of caring from the Leader.

In the Organizational Citizenship Behavior (OCB) variable, the smallest answer value is the OCB-03 indicator, "I am willing to work more than the determined time". This means that the staff of SMK Negeri 1 Karawang are expected to be more loyal to the organization, so that it will create a sense of belonging more to the work and fellow colleagues.

b) Suggestions for future researchers

For further research, seen from the R-Square test results obtained 63.3\% Effect of Leadership, Organizational Citizenship Behavior (OCB) on Employee Performance. At the SMK Negeri 1 Karawang Staff, suggestions that can be considered in future studies that want to research can add samples so that research is more accurate, conduct research in companies with different respondent characteristics and can be used as a reference for examining variables not yet explained in this study, such as Job Satisfaction, Work Motivation, and Work Culture variables.

\section{REFERENCES}

Anymous. 2013. Definition of 'Business'. Investopedia. In :http://www. investopedia com/terms/b/business.asp.

Chun-Fang and Sheng Hsieh. 2012. The Impacts of perceived Organizational Support and Psyhological Sempwerment on Job Performance Effects of Organizational Citizenship Behavior. International journal of hospitality management 31 (1). 180-190.

Fitriastuti. 2013. Pengaruh Kecerdasan Nasional Komitmen Organisasi dan Organisational Citizenship Behavior (OCB) Terhadp Kinerja Karyawan Pada Pegawai Negeri Sipil Organisasi Perindustrian dan Perdagangan Kabupaten Kutai Timur [The Influence of National Intelligence Organizational Commitment and Organizational Citizenship Behavior (OCB) on Employee Performance in Civil Servants of Industry and Trade Organizations in East Kutai Regency]. Mulawarman University Publisher.

Froehlich, Segers, Bossche. 2014. The Influence of Learning Approach, Leadership style, and Organizational Learning Culture on Managers Learning Outcomes in Austrian Banks. Human resource development quarterly 25 (1). 29-57.

Gomes. 2016. Innovation Culture and Performance in Innovation of Products and Processes : a study in Companies of Textile Industry (4). 285-295. 
Goswami, Nair, Beehr, Grossenbasher. 2016. The Relationship of Leaders 'humor and employees 'work Engagement Mediated by Positive, Leadership and Organization Development Journal 37 (8). 1083-1099.

Ghozali, Imam. 2011. "Stuctural Equation Modeling, Metode Alternatif dengan Partial Least Square (PLS) [Structural Equation Modeling, Alternative Methods with Partial Least Square (PLS)]. $4^{\text {th }}$ Ed. Semarang: Diponegoro University Publisher.

Hidayat, A.A. Sugiharjo, R.J. Parashakti, R.D. 2019. MSDM Mengelola Sumber Daya Manusia Di Era Revolusi Industri 4.0 [HRM Manages Human Resources in the Industrial Revolution Era 4.0]. Wahana Resolusi Publisher. Yogyakarta.

Kimbal et al. 2015. Beban Kerja dan Organizational Citizenship Behavior (OCB) Pengaruhnya Terhadap Kinerja Karyawan PT PLN (Persero) wilayah Sulettenggo Area Manado [Workload and Organizational Citizenship Behavior (OCB) Impact on the Performance of the Employees of PT PLN (Persero) in the Sulettenggo Area Manado].

Kiswanto, M. 2010. Pengaruh Kepemimpinan dan Komunikasi Terhadap Kinerja Karyawan Kaltim Pos Samarinda [The Influence of Leadership and Communication on the Performance of East Kalimantan Pos Samarinda Employees]. Samarinda: Politeknik Negeri Samarinda Publisher.

Mangkunegara, A.P. 2009. Manajemen Sumber Daya Manusia Perusahaan : PT Remaja Rosdakarya [Company Human Resource Management: PT Remaja Rosdakarya].

Mangkunegara, A.P. 2012. Manajemen Sumber Daya Manusia Perusahaan : PT Refika Aditama [Company Human Resource Management: PT Refika Aditama].

Noor. Juliansyah. 2011. Metodogi [Penelitian Research methodology], Prenada Media Group, Jakarta.

Padilha, Gomes. 2016. Innovation Culture and Performance in Innovation of Products and Processes : a study in Companies of Textile Industry (4). 285-295.

Robbins, Stephen P. dan Timothy A. Judge. 2015. Perilaku Organisasi [Organizational behavior] translated by Ratna Saraswati dan Fabriella Sirait. Jakarta. Salemba Empat.

Sutrisno. 2010. Manajemen Sumber Daya Manusia [Human Resource Management]. Jakarta: Kencana.

Sugiyono. 2013. Metode Penelitian Pendidikan Pendekatan Kuantatif, Kualitatif, dari R\&D [Educational Research Methods Quantitative, Qualitative, and R\&D Approaches]. Bandung: Alfabeta.

Suli, J. 2013. What Is Human Resources Management? Human Resources Guide. Dalam:http//humanresourcesguide.net/what-is-human-resources management/

Ticoalu. 2013. Organizational Citizenship Behavior (OCB) dan Komitmen Organisasi Pengaruhnya Terhadap Kinerja Karyawan pada PT. Bank Tabungan Pensiunan Nasional (BTPN) Cabang Utama Manado [Organizational Citizenship Behavior (OCB) and Organizational Commitment Impact on Employee Performance at PT. National Pension Savings Bank (BTPN) Manado Main Branch]. Manado : Sam Ratulangi Manado University Publisher.

Utami. 2015. Pengaruh Kepemimpinan dan Motivasi Interpersonal terhadap Kinerja Karyawan pada Biro Perjalanan Wisata "Panen Tour" [The Effect of Leadership and Interpersonal Motivation on Employee Performance in the "Panen Tour" Travel Bureau] Jakarta : Mercu Buana University Publisher.

Veithzal Rivai dan Ella Jauvani Sagala. 2011. Manajemen Sumber Daya Manusia untuk perusahaan dari teori ke praktik [Human Resource Management for companies from theory to practice]. PT. Raja Grafindo, Jakarta.

Wihardi, Pradhanawati, Susanto. 2014. Pengaruh Kepemimpinan dan Lingkungan Sosial Terhadap Kinerja Karyawan Hotel Muria Semarang [The Influence of Leadership and Social Environment on the Performance of the Muria Hotel Semarang Employees]. Semarang : Diponegoro University Publisher. 